\title{
SOIL ORGANIC CARBON, CARBON STOCK AND THEIR RELATIONSHIPS TO PHYSICAL ATTRIBUTES UNDER FOREST SOILS IN CENTRAL AMAZONIA ${ }^{1}$
}

\author{
Jean Dalmo de Oliveira Marques ${ }^{2 *}$, Flávio Jesus Luizão ${ }^{3}$, Wenceslau Geraldes Teixeira ${ }^{4}$, Claudia Marie \\ Vitel $^{5}$ and Elizalane Moura de Araújo Marques²
}

\footnotetext{
${ }^{1}$ Received on 12.04.2013 accepted for publication on 09.12.2015.

${ }^{2}$ Instituto Federal de Educação, Ciência e Tecnologia do Amazonas, Manaus, AM - Brasil. E-mail: <jdomarques@hotmail.com> e $<$ elizalanemarques@ifam.edu.br>.

${ }^{3}$ Instituto Nacional de Pesquisas da Amazônia, Departamento de Ecologia, Manaus, AM - Brasil. E-mail:<luizaoflavio@gmail.com>. ${ }^{4}$ Centro Nacional de Pesquisa de Solos, Rio de Janeiro, RJ - Brasil. E-mail: <wenceslau.teixeira@embrapa.br>.

${ }^{5}$ Instituto Nacional de Pesquisas da Amazônia, Departamento de Silvicultura Tropical, Manaus, AM - Brasil. E-mail:<vitel@inpa.gov.br>.

${ }^{*}$ Corresponding author.
}

\begin{abstract}
The soil carbon under Amazonian forests has an important roles in global changing, making information on the soil content and depths of these stocks are considerable interest in efforts to quantify soil carbon emissions to the atmosphere. This study quantified the content and soil organic carbon stock under primary forest up to $2 \mathrm{~m}$ depth, at different topographic positions, at Cuieiras Biological Reserve, Manaus/ ZF2, $\mathrm{km} 34$, in the Central Amazon, evaluating the soil attributes that may influence the permanence of soil carbon. Soil samples were collected along a transect of $850 \mathrm{~m}$ on topographic gradient Oxisol (plateau), Ultisol (slope) and Spodosol (valley). The stocks of soil carbon were obtained by multiplying the carbon content, soil bulk density and trickiness of soil layers. The watershed was delimited by using STRM and IKONOS images and the carbon contend obtained in the transects was extrapolated as a way to evaluate the potential for carbon stocks in an area of 2678.68 ha. The total SOC was greater in Oxisol followed by Spodosol and Ultisol. It was found direct correlations between the SOC and soil physical attributes. Among the clay soils (Oxisol and Ultisol), the largest stocks of carbon were observed in Oxisol at both the transect (90 to $175.5 \mathrm{Mg}$ $\mathrm{C} \mathrm{ha}^{-1}$ ) as the level of watershed (100.2 to $195.2 \mathrm{Mg} \mathrm{C} \mathrm{ha}^{-1}$ ). The carbon stocks under sandy soil (Spodosol) was greater to clay soils along the transect (160-241 $\left.\mathrm{Mg} \mathrm{C} \mathrm{ha}^{-1}\right)$ and near them in the Watershed (96.90 to 146.01 $\left.\mathrm{Mg} \mathrm{C} \mathrm{ha}^{-1}\right)$.
\end{abstract}

Keywords: Carbon; Soil physical properties; Amazonian forest.

\section{CARBONO ORGANICO DO SOLO, ESTOQUE DE CARBONO E SUA RELAÇÃO COM ATRIBUTOS FÍSICOS SOB SOLOS FLORESTAIS NA AMAZÔNIA CENTRAL}

\begin{abstract}
RESUMO - O carbono do solo sob floresta amazônica tem um papel importante na mudança global, tornando as informações sobre os teores de carbono e profundidades desses estoques são de grande interesse no esforço de quantificar as emissoes de carbono do solo para a atmosfera. Este estudo quantificou os teores e estoques de carbono orgânico do solo sob floresta primária até $2 m$ de profundidade, em diferentes posições topográficas, na Reserva Biológica do Cueiras, Manaus/ZF2, km34, na Amazônia Central; avaliando-se os atributos do solo que podem influenciar na permanência do carbono no solo. Coletaram-se amostras de solos ao longo de um transecto de 850 m num gradiente topográfico Latossolo (platô), Argissolo (vertente) e Espodossolo (baixio). Os estoques de carbono do solo foram obtidos multiplicando a concentração de carbono pela densidade do solo e espessura de camadas do solo. Delimitou-se uma microbacia hidrográfica através de imagens STRM IKONOS extrapolando-se os teores de carbono obtidos no transecto como forma de avaliar o potencial de estocagem de carbono em uma área de 2.678,68 ha. O total de COS foi maior no Latossolo seguido
\end{abstract}


do Espodossolo e Argissolo. Encontrou-se correlações diretas entre o COS e atributos fisicos dos solos. Entre os solos argilosos (Latossolo e Argissolo), os maiores estoques de carbono foram observados sob Latossolo tanto a nivel de transecto (90 a 175,5 $\mathrm{Mg} \mathrm{ha}^{-1} \mathrm{de}$ C) quanto a nível de área da microbacia (100,2 a 195,2

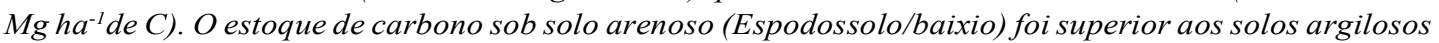
ao longo do transecto (160 a $241 \mathrm{Mg} \mathrm{ha}^{-1}$ de C) e próximo a eles na microbacia hidrográfica (96,90 a 146,01 $\left.\mathrm{Mg} \mathrm{ha}^{-1} \mathrm{de} \mathrm{C}\right)$.

Palavras-chave: Carbono; Propriedades físicas do solo; Floresta Amazônica.

\section{INTRODUÇÃO}

Changes in tropical natural ecosystems may cause reductions in carbon inputs depending of the use, management, physical, chemical and biological soil (SILVA JUNIOR et al., 2009).

The soil kept in natural conditions, under native vegetation, show physical characteristics suitable for the optimal development of plants (SPERA et al., 2004). However, when native ecosystems are changed, the dynamic balance is broken and, usually, causing lower carbon inputs than outputs, leading to reduction in the amount and alteration of quality SOM (soil organic matter) (CERRI et al., 2008).

Factors such as original vegetation, type and soil management, climate, quantity and quality of plant residues (COSTA et al, 2009;. MAIA et al., 2009; FRAZÃO et al., 2010), texture (LUCA et al., 2008 ), mineralogy (ZINN et al., 2007) and soil bulk density (NAVARRETE; TSUTSUKI, 2008) have been described as controlling the magnitude and speed of changing in the content and quality of SOM.

The current concern is for studies which quantify the changes in content and carbon stocks in areas of traditional agriculture (SERGNINI et al., 2013; CERRI et al., 2013), as well as the mensuration carbon losses in Amazonian soils due the replacement of native forest for pasture (DESJARDINS et al., 2004; COSTA et al., 2009;. SILVA JÚNIOR et al., 2009).

Due to its size, characteristics, natural and anthropogenic processes, the Amazon can significantly modify the carbon stocks and water between the biosphere and atmosphere (MARLAND et al., 2008). Thus, carbon study in the soil under primary forest in the Amazon provides a contribution in the field of scientific knowledge through the provision of data about the content and carbon stocks in environmental conservation areas, whereas current studies emphasize only cultivated areas. In addition, part of the estimates about the amount of carbon stored as organic matter, in Amazon soils, in areas of difficult access, based on profile data collected by Radambrasil project between 1973-1986.

The knowledge about carbon and soil physical properties are extremely important to determine management practices which keep carbon in the terrestrial environment and appropriate forms of soil conservation in tropical forests. The latest information on carbon stored in the soil has been used in mathematical models in order to predict potential emissions to the atmosphere and as a way to assess the environmental quality of forest ecosystems.

Therefore, it is necessary to examine the Amazon soils with capacity to store or lose carbon, which, in turn, requires understanding how much of carbon is stored in soils and how quickly it can be stabilized or destabilized. In this context, quantified the content and soil organic carbon stocks under primary forest, up to $2 \mathrm{~m}$ depth, at different topographic positions, evaluating soil attributes that may influence the permanence of carbon in soil.

\section{MATERIALS AND METHODS}

The study area is located in the Cuieiras Biological Reserve of the Instituto Nacional de Pesquisas da Amazônia (INPA). The reserve covers an area of approximately $22.700 \mathrm{ha}$, located $60 \mathrm{~km}$ north of Manaus, Amazonas, Brazil. The site is at kilometer 34 on the ZF-2 service road (approximate geographical coordinates: $2^{\circ} 35^{\prime} 21.08^{\prime \prime} 98 \mathrm{~S}$ and $\left.60^{\circ} 6^{\prime} 53.63^{\prime \prime} \mathrm{W}\right)$. Vegetation in the reserve is "dense ombrophilous forest". That is considered to be primary (not disturbed by nonindigenous occupation). The reserve is distributed between two basins: the Cuieiras River basin $(13,414$ ha) to the West and theTarumã-Açu River basin (9321 ha) to the East (RANZANI, 1980). The topography 
of the transect included in this study covers a sequence of plateau, slope and valley bottom (Luizão et al., 2004). The experiment was conducted in topographic transect of $850 \mathrm{~m}$ consisting of plateau, slope and valley.

Nine permanent plots (with dimension $20 \times 40 \mathrm{~m}$ ), being three each topographical position, for successive collections of soil samples from 2005 to 2010 , one collection, every year, in the same period. Soil samples were collected along a transect of $850 \mathrm{~m}$, in pedological horizons, by opening soil profiles and standards areas during the collection period. The profiles had dimensions of $1.5 \mathrm{~m} \times 1.5 \mathrm{~m} \times 2.0 \mathrm{~m}$. The identification of horizons and morphological description were performed according to Santos et al. (2015).

The granulometric analysis and density of the particles were measured using the pipette and pycnometer methods, according EMBRAPA (1997), respectively. The soil bulk density was determined in undeformed samples, collected with Uhland sampler, in volumetric rings (height $0.05 \mathrm{~m}$ and diameter $0.05 \mathrm{~m}$ ) along the selected layers in five replications.

The determination of the pore size distribution by size was obtained from the samples used for obtaining bulk density, with separation between macro and micropores, by drainage, at $10 \mathrm{kPa}$ pressure. Total porosity was calculated by the relationship between soil bulk density and particle density.

For determination of carbon content used the Fisons Instruments analyzer NC NA 1500, using approximately 25-30 mg of material previously macerated in a mortar and passed at $21,2 \mathrm{~cm}$ mesh sieve, in order to reduce errors associated the grain size.

The soil carbon stocks were calculated by multiplying the carbon content by soil bulk density and the thickness of the sampled soil layer (BERNOUX et al., 1998), considering:

$$
E=\rho_{s} x A x C
$$

where $\mathrm{E}$ is the carbon stock $\left(\mathrm{Mg} \cdot \mathrm{ha}^{-1}\right) ; \rho_{s}$, the soil bulk density $\left(\mathrm{g} \mathrm{cm}^{-3}\right)$; A, the thickness of the sampled soil layer $(\mathrm{cm})$ and $\mathrm{C}$, carbon content in the soil (\%).

The soil carbon stocks were determined in the layers: 0-40 cm, 0-100 cm and 0-200 cm in plateau (Oxisol) and slope (Ultisol). The values of soil carbon stocks were corrected by mass equivalency of the reference area (SISTI et al., 2004).
Under valley soil, the stocks were calculated for the depths: $0-25 \mathrm{~cm}$ and $0-120 \mathrm{~cm}$ due to the intensity of roots on the soil surface and by interference of the water table height.

The values of soil carbon stock were extrapolated for a Igarapé Açu Watershed, with 2.678 .68 ha, belonging to the hydrography of Cueiras in order to estimate the total carbon stock, using the hydrological function of arcgis 9.0 software. With the image STRM (Shuttle Radar Topographic M) 30m accumulations and directions of flows were calculated, allowing the delimitation of the area. Then the STRM and IKONOS images were randomized and using the points collected by the GPS delimited three topographical classes: plateau, slope and valley. It was considered the plateau area with an altitude of between $90-120 \mathrm{~m}$, slope between 75 $90 \mathrm{~m}$ and valley between 50-75 $\mathrm{m}$. Thus, it were calculated the areas corresponding to three distinct classes defined by plateau (41.5\%), slope (35.8\%) and valley (22.6\%) (Figure 1), being possible to estimate the total carbon stock potential considering the soil classes identified along the transect to two meters depth.

The carbon data, physical attributes, soil carbon stocks $(850 \mathrm{~m} /$ transect $)$ and total carbon stocks $(2678.68$ ha) were subjected to analysis of variance and means were compared by 5\% Tukey test. Analysis Pearson correlations were performed to relate $\mathrm{SOC}$ to soil physical attributes.

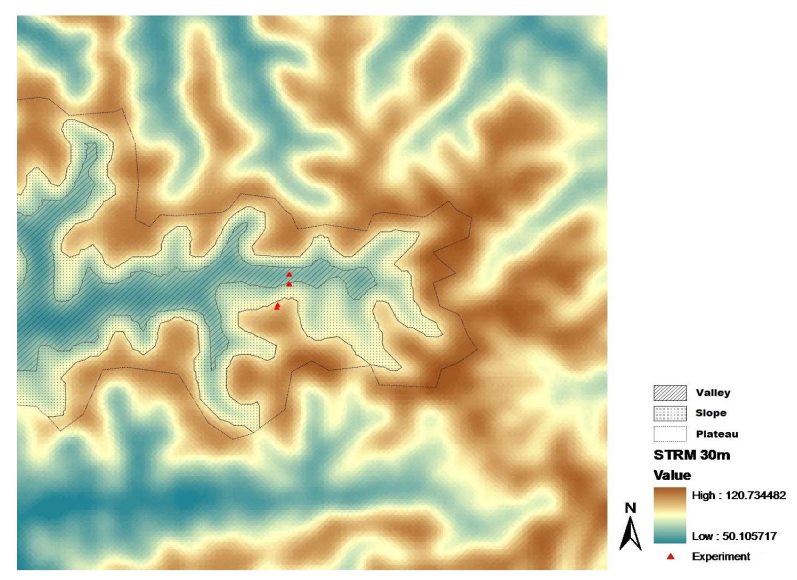

Figure 1 - Picture of the watershed boundary with the demarcation of areas plateau, slope and valley.

Figura 1-Imagem da bacia hidrográfica com as delimitações das áreas de platô, vertente e baixio.

Revista Árvore, Viçosa-MG, v.40, n.2, p.197-208, 2016 


\section{RESULTS}

The soils were classified as oxisol (plateau), ultisol (slope) and spodosol (valley) according to (SOIL SURVEY STAFF, 1998). On the plateau (oxisol), the granulometric analysis revealed clay contents of 687 $\mathrm{g} \mathrm{kg}^{-1}$, on the surface, and of $852 \mathrm{~g} \mathrm{~kg}^{-1}$ until $2 \mathrm{~m} \mathrm{depth}$, indicating a very clay texture (Table 1 ). The ultisol (slope) showed a sandy clay loam textured on surface with $301 \mathrm{~g} \mathrm{~kg}^{-1}$, increasing in depth to $497.63 \mathrm{~g} \mathrm{~kg}^{-}$ ${ }^{1}$, caracterized a clay texture. The spodosol (valley) had a different dynamic, containing clay content between $9 \mathrm{~g} \mathrm{~kg}^{-1}$ to $18 \mathrm{~g} \mathrm{~kg}^{-1}$ caracterized sandy texture. The soil bulk density increases with depth, ranging from $1.05 \mathrm{~g} \mathrm{~cm}^{-3}$ to $1.22 \mathrm{~g} \mathrm{~cm}^{-3}$ in oxisol increasing in the ultisol ranging from $1.20 \mathrm{~g} \mathrm{~cm}^{-3}$ to $1.42 \mathrm{~g} \mathrm{~cm}^{-3}$ and Spodosol from $1.45 \mathrm{~g} \mathrm{~cm}^{-3}$ to $1.72 \mathrm{~g} \mathrm{~cm}^{-3}$. The fractionation of pores showed the oxisol with high porosity $(>0.50$ $\left.\mathrm{m}^{-3} \mathrm{~m}^{-3}\right)$ with predominantly micropores $\left(>0.40 \mathrm{~m}^{-3} \mathrm{~m}^{-}\right.$ ${ }^{3}$ ) and macropores from 0.03 to $0.12 \mathrm{~m}^{-3} \mathrm{~m}^{-3}$. The increased macroporosity in the ultisol ranging from $0.12 \mathrm{~m}^{-3} \mathrm{~m}^{-}$ ${ }^{3}$ to $0.22 \mathrm{~m}^{-3} \mathrm{~m}^{-3}$. The spodosols showed a increase in the macroporosity $\left(0.33 \mathrm{~m}^{-3} \mathrm{~m}^{-3}\right.$ to $\left.0.39 \mathrm{~m}^{-3} \mathrm{~m}^{-3}\right)$, due to the increase of coarse sand particles (Table 1).

The carbon content decreased with increasing depth in both soils, with the highest levels found in the soil surface (Table 1). The oxisol (plateau) showed carbon content from 0.34 to $2.97 \%$, the ultisol (slope) from 0.21 to $2.31 \%$ and the Spodosol (valley) from 0.52 to $4.37 \%$, according with the findings by Luizão et al. (2004). On the surface, Spodosol showed carbon content higher than most clay soils (oxisols and ultisols) (Table 1), in contrast with the results of Luizão et al. (2004) who obtained $0.5 \%$ to $1.0 \%(5 \mathrm{~cm})$ and 0.2 to $0.8(10 \mathrm{~cm})$, perhaps due the dynamic valley area, that is influenced by fluctuations in the water table height and by action of the thin roots in the soil surface, providing carbon in higher concentrations in the superficial layers. In Spodosol it is common the accumulation of the organic matter on surface, resulting humification process (SARMIENTO et al., 2005) due the high diversity of litter on the system (NAVARRETE; TSUTSUKI, 2008), with high amount of lignin (STALLCUP et al., 2006) associated a slow rate of decomposition (LUIZÃO et al., 2004) due preference feed shredders invertebrates, microbial decomposition and susceptibility physical fragmentation (GRAÇA; ZIMMER, 2005).

We found direct correlations between SOC and soil bulk density, clay content, porosity, macroporosity and microporosity (Table 2), confirming that these soil properties may interfere in the SOC. Positive correlation was obatained between SOC and macroporosity $(r=0.60)$ and total porosity $(r=0.82)$ on the plateau (oxisol); with total porosity $(r=0.87)$, macroporosity $(r=0.72)$ and microporosity $(r=0.61)$ in the valley (spodosol); negative relationshiphs were found with clay content $(r=-0.87)$ in oxisol and ultisol $(\mathrm{r}=-0.81)$, soil bulk density on the plateau (oxisol) $(\mathrm{r}=-0.81)$, slope (ultisol) $(\mathrm{r}=-0.80)$ and

Table 1 - Soil physical attributes in the transect of the Cueiras Biological Reserve, Manaus, AM.

Tabela 1 - Atributos físicos dos solos no transecto na Reserva Biologica do Cuieiras, Manaus, AM.

\begin{tabular}{|c|c|c|c|c|c|c|c|c|c|}
\hline \multirow[t]{2}{*}{ Soils } & \multirow{2}{*}{$\begin{array}{c}\text { Depht } \\
(\mathrm{cm})\end{array}$} & Clay & Silt & Total sand & \multirow{2}{*}{$\begin{array}{c}\rho \\
\left(\mathrm{g} \mathrm{cm}^{-3}\right)\end{array}$} & \multirow{2}{*}{$\begin{array}{c}\text { Carbon } \\
(\%)\end{array}$} & $\mathrm{Pt}$ & $\mathrm{Ma}$ & Mi \\
\hline & & $\ldots \ldots$ & $\ldots\left(\mathrm{gkg}^{-1}\right)$. & ......... & & & \multicolumn{3}{|c|}{$\ldots \ldots \ldots \ldots\left(\mathrm{m}^{3} \mathrm{~m}^{-3}\right) \ldots \ldots \ldots \ldots$} \\
\hline \multirow{5}{*}{$\begin{array}{c}\text { Oxisol } \\
\text { (Plateau) }\end{array}$} & $0-10$ & $687,08 \mathrm{c}$ & $64,18 \mathrm{a}$ & $248,73 \mathrm{a}$ & $1,05 \mathrm{c}$ & $2,97 \mathrm{a}$ & $0,55 \mathrm{a}$ & $0,12 \mathrm{a}$ & $0,42 \mathrm{c}$ \\
\hline & $10-45$ & 819,46 a & $27,20 \mathrm{c}$ & $153,33 \mathrm{c}$ & $1,22 \mathrm{a}$ & $1,36 \mathrm{~b}$ & $0,48 \mathrm{~b}$ & $0,03 \mathrm{c}$ & $0,45 \mathrm{~b}$ \\
\hline & $45-82$ & $788,66 \mathrm{~b}$ & $17,25 \mathrm{~d}$ & $194,08 \mathrm{~b}$ & $1,19 \mathrm{~b}$ & $0,65 \mathrm{c}$ & $0,52 \mathrm{a}$ & $0,06 \mathrm{~b}$ & $0,45 \mathrm{~b}$ \\
\hline & $82-108$ & $855,37 \mathrm{a}$ & $15,50 \mathrm{~d}$ & $129,11 \mathrm{~d}$ & $1,22 \mathrm{a}$ & $0,52 \mathrm{~d}$ & $0,52 \mathrm{a}$ & $0,05 \mathrm{~b}$ & $0,47 \mathrm{a}$ \\
\hline & $108-200^{+}$ & 852,79 a & $38,10 \mathrm{~b}$ & $109,10 \mathrm{e}$ & $1,22 \mathrm{a}$ & $0,34 \mathrm{e}$ & 0,53 a & $0,05 \mathrm{~b}$ & 0,47 a \\
\hline \multirow{6}{*}{$\begin{array}{l}\text { Ultisol } \\
\text { (Slope) }\end{array}$} & $0-14$ & $301,01 \mathrm{~d}$ & $74,86 \mathrm{a}$ & $624,12 \mathrm{a}$ & $1,20 \mathrm{~b}$ & $2,31 \mathrm{a}$ & $0,49 \mathrm{~b}$ & $0,21 \mathrm{a}$ & $0,28 \mathrm{~d}$ \\
\hline & $14-38$ & $422,45 \mathrm{c}$ & $44,77 \mathrm{~d}$ & $532,77 \mathrm{~b}$ & $1,30 \mathrm{a}$ & $1,00 \mathrm{~b}$ & $0,45 \mathrm{~b}$ & $0,12 \mathrm{~d}$ & $0,32 \mathrm{ab}$ \\
\hline & $38-59$ & $478,24 \mathrm{~b}$ & $47,20 \mathrm{~d}$ & $474,53 \mathrm{c}$ & $1,34 \mathrm{a}$ & $0,57 \mathrm{c}$ & $0,52 \mathrm{a}$ & $0,21 \mathrm{a}$ & $0,30 \mathrm{c}$ \\
\hline & $59-84$ & 493,31 a & $44,98 \mathrm{~d}$ & $461,70 \mathrm{~d}$ & $1,35 \mathrm{a}$ & $0,42 \mathrm{~d}$ & $0,51 \mathrm{a}$ & $0,19 \mathrm{~b}$ & $0,31 \mathrm{bc}$ \\
\hline & 84-138 & 497,63 a & $54,56 \mathrm{~b}$ & $447,80 \mathrm{~d}$ & $1,40 \mathrm{a}$ & $0,28 \mathrm{e}$ & $0,54 \mathrm{a}$ & $0,22 \mathrm{a}$ & $0,32 \mathrm{ab}$ \\
\hline & $138-200^{+}$ & $464,21 \mathrm{~b}$ & $50,88 \mathrm{c}$ & $484,90 \mathrm{c}$ & 1,42 a & $0,21 \mathrm{e}$ & $0,51 \mathrm{a}$ & $0,17 \mathrm{c}$ & $0,33 \mathrm{a}$ \\
\hline \multirow{3}{*}{$\begin{array}{c}\text { Spodosol } \\
\text { (Valley) }\end{array}$} & $0-25$ & $18,12 \mathrm{a}$ & $16,98 \mathrm{a}$ & $964,89 \mathrm{a}$ & $1,45 \mathrm{c}$ & $4,37 \mathrm{a}$ & 0,48 a & $0,39 \mathrm{a}$ & 0,08 a \\
\hline & $25-59$ & $10,00 \mathrm{~b}$ & $6,52 \mathrm{~b}$ & 983,47 a & $1,64 \mathrm{~b}$ & $0,61 \mathrm{~b}$ & $0,39 \mathrm{~b}$ & $0,36 \mathrm{~b}$ & $0,02 \quad b$ \\
\hline & $59-120^{+}$ & $9,00 \mathrm{~b}$ & $7,66 \mathrm{~b}$ & 983,33 a & $1,72 \mathrm{a}$ & $0,52 \mathrm{c}$ & $0,39 \mathrm{~b}$ & $0,33 \mathrm{c}$ & $0,03 \mathrm{~b}$ \\
\hline
\end{tabular}

The data represent the mean values $(n=5)$. Means followed by the same letter in the same column are not significantly different by the $\mathrm{F}$-test in an analysis of variance $(\mathrm{p}<0.05) . \rho=$ soil bulk density; $\mathrm{Pt}=$ total porosity; Ma = macroporosity; Mi = microporosity. 
Table 2 - Pearson correlation coefficient between attributes and soil carbon contents $(\mathrm{n}=5)$.

Tabela 2 - Coeficiente de correlação de Pearson entre Atributos do solo e os teores de carbono $(n=5)$.

\begin{tabular}{lcc}
\hline Soil attributes & & Carbon $(\%)$ \\
\hline Clay content $\left(\mathrm{g} \mathrm{kg}^{-1}\right)$ & Oxisol - Plateau & $-0,87^{*}$ \\
Soil bulk density $\left(\mathrm{g} \mathrm{cm}^{-3}\right)$ & & $-0,81^{*}$ \\
Total porosity $\left(\mathrm{m}^{-3} \mathrm{~m}^{-3}\right)$ & & $0,82^{*}$ \\
Macroporosity $\left(\mathrm{m}^{-3} \mathrm{~m}^{-3}\right)$ & $0,60^{*}$ \\
Microporosity $\left(\mathrm{m}^{-3} \mathrm{~m}^{-3}\right)$ & & $-0,71^{*}$ \\
\hline & Ultisol - Slope & $-0,81^{*}$ \\
\hline Clay content $\left(\mathrm{g} \mathrm{kg}^{-1}\right)$ & & $-0,80^{*}$ \\
Soil bulk density $\left(\mathrm{g} \mathrm{cm}^{-3}\right)$ & & $-0,33^{\text {ns }}$ \\
Total porosity $\left(\mathrm{m}^{-3} \mathrm{~m}^{-3}\right)$ & & $0,10^{\mathrm{ns}}$ \\
Macroporosity $\left(\mathrm{m}^{-3} \mathrm{~m}^{-3}\right)$ & & $-0,60^{*}$ \\
Microporosity $\left(\mathrm{m}^{-3} \mathrm{~m}^{-3}\right)$ & Spodosol - Valley & \\
\hline & & $0,45^{\mathrm{ns}}$ \\
\hline Clay content $\left(\mathrm{g} \mathrm{kg}^{-1}\right)$ & & $-0,80^{*}$ \\
Soil bulk density $\left(\mathrm{g} \mathrm{cm}^{-3}\right)$ & & $0,87^{*}$ \\
Total porosity $\left(\mathrm{m}^{-3} \mathrm{~m}^{-3}\right)$ & & $0,72^{*}$ \\
Macroporosity $\left(\mathrm{m}^{-3} \mathrm{~m}^{-3}\right)$ & & $0,61^{*}$ \\
Microporosity $\left(\mathrm{m}^{-3} \mathrm{~m}^{-3}\right)$ & &
\end{tabular}

Significant correlation $*$ and $\mathrm{ns}=$ no significant at $5 \%$ probability.

valley (Spodosol) $(\mathrm{r}=-0.80)$ with micropores on the plateau (Oxisol) $(\mathrm{r}=-0.71)$ and slope (Ultisol) $(\mathrm{r}=-0.60)($ Table 2$)$.

The table 3 shows the total carbon stocks up to $2.0 \mathrm{~m}$ depth along the layers $0-40,0-100$ and $0-200 \mathrm{~cm}$ belonging to transect Igarapé Açu Watershed (Cuieiras Biological Reserve Cueiras/ZF2). Despite the carbon decrease with depth (Table 1), stocks did not follow this trend, due to the increase of soil bulk density in depth and thickness of soil horizons. Among the clay soil (oxisol/plateau and ultisol/slope), the largest carbon stocks were observed under oxisol in both areas studied (90 to $175.5 \mathrm{Mg} \mathrm{ha}^{-1}$ of $\mathrm{C}$ in the $850 \mathrm{~m}$ transect) and (100,2 to $195.2 \mathrm{tha}^{-1}$ of $\mathrm{C}$ in the Igarapé Açu Watershed). The carbon stocks in sandy soils (spodosol/valley)

Table 3 - Mean values of carbon stocks $\left(\mathrm{Mg} \mathrm{C} \mathrm{ha}^{-1}\right)$ obtained over 5 years of sampling.

Tabela 3 - Valores médios dos estoques de carbono $\left(\mathrm{Mg} \mathrm{ha}^{-1}\right.$ de C) obtidos ao longo de 5 anos de amostragem.

\begin{tabular}{lcc}
\hline $\begin{array}{c}\text { Depth } \\
(\mathrm{cm})\end{array}$ & \multicolumn{2}{c}{ Carbon Stock } \\
\cline { 2 - 3 } & (Transect of $850 \mathrm{~m})$ & $\begin{array}{c}\text { Igarapé Açu Watershed } \\
\text { (Area: 2.678,68 ha) }\end{array}$ \\
\hline & Oxisol - Plateau & $100.210,8 \mathrm{Ac}$ \\
\hline $0-40$ & $90 \mathrm{Ac}$ & $151.838,4 \mathrm{Ab}$ \\
$0-100$ & $136,5 \mathrm{Ab}$ & $195.236,7 \mathrm{Aa}$ \\
$0-200$ & $175,5 \mathrm{Aa}$ & $80.470,8 \mathrm{Bc}$ \\
\hline & Ultisol - Slope & $111.477,1 \mathrm{Bb}$ \\
\hline $0-40$ & $84 \mathrm{Ac}$ & $152.611,9 \mathrm{Ba}$ \\
$0-100$ & $116 \mathrm{Bb}$ & $96.902,3 \mathrm{Ab}$ \\
$0-200$ & $159 \mathrm{Ba}$ & $146.018,0 \mathrm{Aa}$ \\
\hline
\end{tabular}

The uppercase letters compare the layers between the soil types, the minute latters compare the layers each other in the same soil type $(\mathrm{p}<0,05$; Tukey HSD). 
were higher than clay soils along the transect (160 to $241 \mathrm{Mg} \mathrm{ha}^{-1}$ of C) and almost these soils in the Igarapé Asu Watershed (96.902 to $146.018 \mathrm{Mg} \mathrm{ha}^{-1}$ of C).

\section{DISCUSSION}

Variations in physical attributes of soils along the topographical gradient under primary forest influence content and carbon stock. The studied soils have a greater capacity to store carbon in depth. The largest carbon content obtained in surface layers are explained due the surface soil suffer greater interference of organic matter deposited by forest. Oliveira et al. (2008) emphasize that the soil surface layers are more sensitive to variations of carbon due to the action of microorganisms in the SOM.

With depht increase, it is obtained an increase in clay content and a decrease of organic carbon in the soil due the reduced contact with the surface layers (Table 1), resulting in negative correlations between carbon and clay content (Table 2). The increase in microporosity content and soil bulk density in depth coincide with lower carbon contents, causing negative correlations (Table 2), whereas the higher macropore content relate to increases in carbon content and provided positive correlations (Table 1 and 2).

The correlations between carbon content and soil physics attributes found in this research has been observed in other recent studies (ZINN et al., 2007; COSTA et al., 2008; MARQUES et al., 2008; LANZANOVA et al., 2010; CALONEGO et al., 2012; HICKMANN et al., 2012;. CHAUDHARI et al., 2013;. HUGAR; SORAGANVI, 2014). Although the carbon content decrease in depth, physical attributes of Amazon soils such as clay content, soil bulk density, amount of macropores and micropores may exert the protection of the carbon contained in the soil (MARQUES et al., 2010, 2012) leading to increases in carbon stocks in depth.

The reduced macroporosity and high microporosity in depth on the plateau (Oxisol) assist in carbon retention in the subsurface horizon, allowing for greater stability. On the other hand, the valley soils (Spodosol), due to higher percentage of sand, are more unstable in the soil carbon maintenance that may be released to the atmosphere more easily if the soil is changed.
It is found a greater correlation between carbon content with soil structure represented by pore distribution in the soil, probably caused by aggregation of the SOM with clay particles forming micro and macro aggregates, which may cause physical barrier to carbon decomposition. The positive and negative correlations found (Table 2), shows the importance of organic matter how soil structural component, being considered an efficient soil quality indicator, because it is sensitive to management changes and exert influence on the soil microbial activity (RAMOS et al., 2010). The structure of Amazonian soils under forest allows carbon to remain stored, avoiding losses to the atmosphere. Modifications in these attributes may cause major changes in content and carbon stocks.

Other studies have shown the behavior of SOC in depth, emphasizing that the total carbon stored below $1 \mathrm{~m}$ may actually be higher than the carbon stock above $1 \mathrm{~m}$ (NEPSTAD et al., 1994; TRUMBORE et al., 1995 ). Nepstad et al. (1994) were the first to emphasize the importance of carbon in depth under tropical forest soils. Conducted studies in Pará showed that the forest soil below the depth of $1 \mathrm{~m}$ contained more carbon than biomass on the surface, attributing this behavior to the thickness of the subsurface horizons and roots activity.

The amount of carbon stored in the subsurface horizons may occur due to the slow movement of SOM in the Bw horizons when compared to the surface Ap horizons. The clayey texture or very clayey in depth and distribution of pores cause an accumulate of carbon over the years (JONES et al., 2005; LORENZ; LAL, 2005).

In recent years, research concerning dynamics and carbon in the soil is limited to a few areas, of sparse periods in time, some, without setting depths, with units of different magnitudes and without precise sampling of soil bulk density (Table 4). Carbon stock estimates in tropical soils and in the Amazonian region have been executed in different locations, with results also very varied (Table 4). A comparison could only be from the same units of mass and area which is impeded by different studied dephts.

The results of this study are agree to those observed in some studies to Amazon soils (SOMMER et al., 2000), equivalent to those of other forest soils in tropical regions (VELDKAMP et al., 2003), above 
Table 4 - Studies on carbon stocks in tropical soils.

Tabela 4-Estudos realizados sobre estoque de carbono em Solos Tropicais.

\begin{tabular}{|c|c|c|c|c|}
\hline Author & Soil types or localization & Carbon stock & Greatness unit & Depht \\
\hline Batjes (1999) & Tropical soils & 616 à 640 & Gt C & Até $2 \mathrm{~m}$ \\
\hline Batjes and Dijkshoorn (1999) & Oxisol & 50,5 & $\mathrm{t} \mathrm{ha}^{-1}$ & $0,0-0,3 \mathrm{~m}$ \\
\hline Batjes and Dijkshoorn (1999) & Ultisol & 44 & $\mathrm{t} \mathrm{ha}^{-1}$ & $0,0-0,3 \mathrm{~m}$ \\
\hline Batjes and Dijkshoorn (1999) & Amazonian soils & 66 & $\mathrm{Pg} \mathrm{C}$ & No informed \\
\hline $\begin{array}{l}\text { (BERNOUX 1998; BATJES, } \\
\text { DIJKSHOORN, 1999) }\end{array}$ & Soils under forest & 73 à 98 & $\mathrm{Mg} \mathrm{ha}^{-1}$ & $0,0-1,0 \mathrm{~m}$ \\
\hline Bernoux et al. (2001) & OxisolUltisolSpodosol & $7,76 \quad 6,518,31$ & $\mathrm{kgCm}^{-2}$ & Up to $1,0 \mathrm{~m}$ \\
\hline Bernoux et al. (2002) & Northwest Mato Grosso & 45 & $\mathrm{t} \mathrm{ha}^{-1}$ & $0,0-0,3 \mathrm{~m}$ \\
\hline $\begin{array}{l}\text { (BOHN 1976; MORAES et al. } \\
\text { 1995; BATJES, DIJKSHOORN } \\
\text { 1999) }\end{array}$ & $\begin{array}{l}\text { Acre, Legal Amazon, } \\
\text { Amazonian region and } \\
\text { South America(Oxisol } \\
\text { and Ultisol) }\end{array}$ & $\begin{array}{c}6,3-5,9 ; 8,5-9,3 \\
10,2 \text { e } 12,0\end{array}$ & $\mathrm{kgm}^{-2}$ & $0,0-1,0 \mathrm{~m}$ \\
\hline BUSO et al. (2007) & Oxisol and Ultisol & 34,30 e 35,40 & $\mathrm{t} \mathrm{ha}^{-1}$ & $0,0-0,3 \mathrm{~m}$ \\
\hline $\begin{array}{l}\text { (BOHN 1976; MORAES et al. } \\
\text { 1995; BATJES, DIJKSHOORN } \\
\text { 1999) }\end{array}$ & $\begin{array}{l}\text { Acre, Legal Amazon, } \\
\text { Amazonianregion and } \\
\text { South America(Ultisol) }\end{array}$ & $\begin{array}{c}5,8-6,1 ; 9,5 ; 8,5 \\
\text { e } 8,0\end{array}$ & $\mathrm{kgm}^{-2}$ & $0,0-1,0 \mathrm{~m}$ \\
\hline Cerri et al. (2004) & Soils under forest/Rondônia & 24 à 26 & $\mathrm{t} \mathrm{ha}^{-1}$ & $0,0-0,2 \mathrm{~m}$ \\
\hline Cerri et al. (2006) & Brazilian Amazon & 3,5 & $\mathrm{Tg} \mathrm{C}$ ano $^{-1}$ & $0,0-0,3 \mathrm{~m}$ \\
\hline Cerri et al. (2007) & Amazon soils & $41-47$ & $\mathrm{Pg} \mathrm{C}$ & Up to $1,0 \mathrm{~m}$ \\
\hline Clark (2000) & $\begin{array}{l}\text { Soils under Tropical } \\
\text { Forest/Costa Rica }\end{array}$ & $120-200$ & $\mathrm{MgCha}^{-1}$ & $\mathrm{Up}$ to $1,0 \mathrm{~m}$ \\
\hline Clark (2002) & $\begin{array}{c}\text { Soils under Tropical } \\
\text { Forest/Costa Rica/Inceptisol }\end{array}$ & 191,1 & $\mathrm{MgCha}^{-1}$ & $\mathrm{Up}$ to $1,0 \mathrm{~m}$ \\
\hline Clark (2002) & $\begin{array}{c}\text { Soils under Tropical } \\
\text { Forest/Costa Rica e Ultisol } \\
\text { (at plateau and slope) }\end{array}$ & 224,2 e 184,6 & $\mathrm{MgCha}^{-1}$ & $\mathrm{Up}$ to $1,0 \mathrm{~m}$ \\
\hline Desjardins et al. (2004) & $\begin{array}{c}\text { Soils near of Manaus e } \\
\text { Marabá soils }\end{array}$ & $\begin{array}{c}5,5 \text { à } 6,1 \text { e } 2,9 \\
\text { à } 3,4\end{array}$ & $\mathrm{kgm}^{-2}$ & $\mathrm{Up}$ to $20 \mathrm{~cm}$ \\
\hline Eswaran et al. (1993) & Tropical soils & 506 & $\mathrm{Pg} \mathrm{C}$ & No informed \\
\hline Fearnside $(1997,2000,2003)$ & Legal Amazon & 138 & $\mathrm{GtC}$ & Até $8,0 \mathrm{~m}$ \\
\hline Filho et al. (2006) & Mato Grosso & 56,73 à 64,35 & $\mathrm{t} \mathrm{ha}^{-1}$ & $0,0-0,6 \mathrm{~m}$ \\
\hline IBGE (2012) & Legal Amazon & 55,7 & $\mathrm{tCha}^{-1}$ & $0,5 \mathrm{~m}$ \\
\hline IBGE (2012) & Legal Amazon & 95,7 & $\mathrm{tCha}^{-1}$ & $1,0 \mathrm{~m}$ \\
\hline Jobbagy and Jackson, (2000) & Tropical soils & 474 & Gt C & $\mathrm{Up}$ to $3,0 \mathrm{~m}$ \\
\hline Jobbagy and Jackson (2000) & Tropical soils & 1037 & Gt C & Below $3,0 \mathrm{~m}$ \\
\hline Moraes (1995) & Tropical soils & 22 & $\mathrm{kgCm}^{-2}$ & Up to $1,0 \mathrm{~m}$ \\
\hline Moraes et al. (1996) & $\begin{array}{c}\text { Soils under forest/ } \\
\text { Southwest amazon basin }\end{array}$ & 37 & $\mathrm{t} \mathrm{ha}^{-1}$ & $0,0-0,3 \mathrm{~m}$ \\
\hline Moraes et al. (1995) & Amazon basin soils & $45 \times 10^{6}$ & $\mathrm{Pg} \mathrm{C}$ & Até $1,0 \mathrm{~m}$ \\
\hline Moraes et al. (1995) & Amazon basin soils & $20 \times 10^{6}$ & $\mathrm{Pg} \mathrm{C}$ & $0,0-0,2 \mathrm{~m}$ \\
\hline Melo (2003) & Acre soils & 1 & $\mathrm{Pg} \mathrm{C}$ & $0,0-1,0 \mathrm{~m}$ \\
\hline Melo (2003) & Acre soils - Ultisol & 3,5 à 3,6 & $\mathrm{kgm}^{-2}$ & $0,0-0,3 \mathrm{~m}$ \\
\hline Melo (2003) & Acre soils - Oxisol & 3,3 à 4,2 & $\mathrm{kgm}^{-2}$ & $0,0-0,3 \mathrm{~m}$ \\
\hline Melo (2003) & Acre soils - Ultisol & 5,8 à 6,8 & $\mathrm{kgm}^{-2}$ & $0,0-1,0 \mathrm{~m}$ \\
\hline Melo (2003) & Acre soils - Oxisol & 5,9 à 7,6 & $\mathrm{kgm}^{-2}$ & $0,0-1,0 \mathrm{~m}$ \\
\hline Neil et al. (1997) & Rondônia - Nova Vida & 32,3 & $\mathrm{t} \mathrm{ha}^{-1}$ & $0,0-0,3 \mathrm{~m}$ \\
\hline Neil et al. (1997) & Rondônia - Porto Velho & 62 & $\mathrm{t} \mathrm{ha}^{-1}$ & $0,0-0,3 \mathrm{~m}$ \\
\hline
\end{tabular}


Table 4 - Cont

Tabela 4 - Cont.

\begin{tabular}{|c|c|c|c|c|}
\hline Post et al. (1982) & Tropical soils & $3 \overline{16}$ & $\mathrm{GtC}$ & $\overline{\mathrm{Up}} \overline{\text { to }} \overline{1,0} \overline{\mathrm{m}}$ \\
\hline Potter et al. (1998) & Tropical soils - Amazonia & 15,5 & $\mathrm{kgCm}^{-2}$ & $\mathrm{Up}$ to $1,0 \mathrm{~m}$ \\
\hline Potter et al. (1998) & Tropical soils - Amazonia & 106 & $\mathrm{Pg} \mathrm{C}$ & $\mathrm{Up}$ to $1,0 \mathrm{~m}$ \\
\hline Potter et al. (1998) & Tropical soils - Amazonia & 74 & $\mathrm{Pg} \mathrm{C}$ & Up to $1,0 \mathrm{~m}$ \\
\hline RADAMBRASIL (1981) & Tropical soils/Amazonia & 30 & $\mathrm{kgCm}^{-2}$ & $\mathrm{Up}$ to $1,0 \mathrm{~m}$ \\
\hline$\overline{\text { Salimon (2007) }}$ & $\begin{array}{l}\text { Ultisol/Secundary forest } \\
\text { with } 11 \text { years and } 3 \text { years; } \\
\text { Southwest amazonian: } \\
\text { Peixoto, respectively. }\end{array}$ & $\begin{array}{l}14 \text { à } 44 \text { e } 10 \\
\text { à } 38\end{array}$ & $\mathrm{Mg} \mathrm{C} \mathrm{ha}^{-1}$ & $0-60 \mathrm{~cm}$ \\
\hline Salimon (2007) & $\begin{array}{c}\text { Ultisol/Secundary forest with } \\
3 \text { years; Southwest a } \\
\text { mazonian: Humaitá }\end{array}$ & 14 à 41 & $\mathrm{Mg} \mathrm{C} \mathrm{ha}^{-1}$ & $0-60 \mathrm{~cm}$ \\
\hline Salimon (2007) & $\begin{array}{l}\text { Legal reserve/ Southwest } \\
\text { amazonian: Peixoto e } \\
\text { Humaitá, respectively }\end{array}$ & $\begin{array}{c}14 \text { à } 45 \text { e } 11 \\
\text { à } 33\end{array}$ & $\mathrm{Mg} \mathrm{C} \mathrm{ha-1}^{-1}$ & $0-60 \mathrm{~cm}$ \\
\hline Sommer et al. (2000) & Oxisol - Pará & 143 & $\mathrm{Mg} \mathrm{C} \mathrm{ha}^{-1}$ & Below 3,0 m \\
\hline Trumbore et al. (1990) & Ultisol/Curuá-Una/Pará & 54 & $\mathrm{t} \mathrm{Cha}^{-1}$ & $60 \mathrm{~cm}$ \\
\hline Trumbore et al. (1990) & Ultisol/Curuá-Una/Pará & 76 & $\mathrm{t} \mathrm{Cha}^{-1}$ & $60-150 \mathrm{~cm}$ \\
\hline Trumbore et al. (1995) & Tropical soils & 168 & $\mathrm{Mg} \mathrm{C} \mathrm{ha}^{-1}$ & Below 3,0 m \\
\hline Trumbore et al. (1995) & Paragominas soils/Pará & 155 & $\mathrm{t} \mathrm{Cha}^{-1}$ & $1,0-8,0 \mathrm{~m}$ \\
\hline Trumbore et al. (1995) & $\begin{array}{l}\text { Extrapolation to the } \\
\text { Amazonian region }\end{array}$ & $138-276$ & $\mathrm{Gt} \mathrm{Cha}^{-1}$ & Até $8,0 \mathrm{~m}$ \\
\hline Veldkamp et al. (2003) & $\begin{array}{l}\text { Tropical soils under } \\
\text { Forest/Costa Rica }\end{array}$ & $90-130$ & $\mathrm{Mg} \mathrm{C} \mathrm{ha}^{-1}$ & Above $1,0 \mathrm{~m}$ \\
\hline Veldkamp et al. (2003) & $\begin{array}{l}\text { Tropical residual soils } \\
\text { under Forest/Costa }\end{array}$ & 330 & $\mathrm{Mg} \mathrm{C} \mathrm{ha}^{-1}$ & Below $3 \mathrm{~m}$ \\
\hline Veldkamp et al. (2003) & $\begin{array}{l}\text { Tropical alluvial soils under } \\
\text { Forest/Costa Rica }\end{array}$ & 214 & $\mathrm{Mg} \mathrm{C} \mathrm{ha}^{-1}$ & Below $3 \mathrm{~m}$ \\
\hline Veldkamp et al. (2003) & $\begin{array}{l}\text { Tropical residual soils } \\
\text { under Pasture/Costa Rica }\end{array}$ & 300 & $\mathrm{Mg} \mathrm{C} \mathrm{ha}^{-1}$ & Below $3 \mathrm{~m}$ \\
\hline Veldkamp et al. (2003) & $\begin{array}{c}\text { Tropical alluvial soils under } \\
\text { Pasture/Costa Rica }\end{array}$ & 201 & $\mathrm{Mg} \mathrm{C} \mathrm{ha}^{-1}$ & Below $3 \mathrm{~m}$ \\
\hline
\end{tabular}

$\mathrm{GtC}=$ gigaton of carbono; $\mathrm{kgCha}^{-1}=\mathrm{kilogram}$ of carbon per hectare; $\mathrm{tCha}^{-1}=$ ton of carbon per hectare; $\mathrm{PgC}=$ pentagram $\mathrm{f}$ carbon; $\mathrm{MgCha}^{-1}=$ megagramo of carbon per hectare.

(SALIMON, 2007 ) and below (POTTER et al., 1998) other conducted studies in other areas of the Amazon. Recent review of carbon stock in the first 0.5 and $1.0 \mathrm{~m}$ depths estimated values between 55.7 and 95.7 $\mathrm{t} \mathrm{Cha}^{-1}$, respectively. This behavior has also been observed in other studies ranging from 0.1 to 208.7 t C ha ${ }^{-1}$ at $0.5 \mathrm{~m}$ depth and from 95.7 to $250.5 \mathrm{t} \mathrm{C}$ $\mathrm{ha}^{-1} \mathrm{~m}$ depth (IBGE, 2012), similar to those in this study. The differences between the results in this study (Table 3 ) and other published data (Table 4) are related to soil type, location, size of the sampling area, magnitude unit, collected depths, soil horizon thickness, soil bulk density (estimated or determined), soil type, vegetation type and topographic position (Table 4).

Revista Árvore, Viçosa-MG, v.40, n.2, p.197-208, 2016
The results of this study confirm the reported Fearnside (2006), providing that a removal Amazonian forest would contribute to a significant feedback, intensifying the greenhouse effect, both by the release of forest biomass carbon (HUNTINGFORD et al., 2004) as by the release of soil carbon (JONES et al., 2005). Despite information of the potential to sequester carbon is faster in the tropics, mainly in vegetation, to a lesser extent, in the surface layers of the soil, the results showed the potential of the soils studied to store carbon. Although there are not enough information about the potential changes in the soil at great depths (MUTUAL et al., 2005), the studied soil classes have physical attributes which can contribute positively to the carbon protection on the soil. 


\section{CONCLUSIONS}

The soils under Amazonian forests, along the topographic gradient, has great potential to store carbon in depth, being influenced by soil physical properties, soil type and landscape position.

The oxisol has the highest carbon content up to 2.0 depth, followed by spodosol and ultisol.

The Spodosol has large stock of carbon up to 120 $\mathrm{cm}$ produndidade, which can be easily lost in exploitative situations because the soil is sandy.

These results suggests the need for preservation of soils under tropical Forest because changes in forest cover would decrease content and carbon stocks.

\section{ACKNOWLEDGEMENTS}

The authors would like to thank the LBA, PELD, PPG7 Project, and the CNPq for financial support.

\section{REFERENCES}

BALSEIRO, E.; ALBARIÑO, R. C-N mismatch in the leaf litter-shredder relationship of an Andean Patagonian stream detritivore. Journal of the North American Benthological Society, v.25, p.607-615, 2006.

BERNOUX, M.; ARROUAYS, D.; CERRI, C.C.; BOURENNANE, H. Modelling vertical distribution of carbon in Oxisols of the Western Brazilian Amazon (Rondônia). Soil Science, v. 163, p.941951,1998

CALONEGO, J.C.; SANTOS,C.H.; TIRITAN, C.S.; CUNHA JÚNIOR, J.R. Estoques de carbono e propriedades físicas de solos submetidos a diferentes sistemas de manejo. Revista Caatinga, v.25, n.2, p.128-135, 2012.

CERRI, C.E.P.; FEIGL, B.; CERRI, C.C. Dinâmica da matéria orgânica do solo na Amazônia. In: SANTOS, G.A.; SILVA, L.S.; CANELLAS, L.P.; CAMARGO, F.O. (Ed.). Fundamentos da matéria orgânica do solo: ecossistemas tropicais e subtropicais. 2.ed. Porto Alegre: Metrópole, 2008. p.325-358.

CERRI, C.E.P.; GALDOS, M.V.; CARVALHO, J.L.N.; FEIGL, B.J.; CERRI, C.C. Quantifying soil carbon stocks and greenhouse gas fluxes in the surgarcane agrosystem: point of view. Scientia Agricola, v.70, p.361-368, 2013.

CHAUDHARI, P.R.; AHIRE, D.V.; AHIRE, V.D.; CHKRAVARTY, M.; MAITY, S. Soil bulk density as related to soil texture, organic matter content and available total nutrients of coimbatore soil.

International Journal of Scientific and Research Publications, v.3, p.22503153, 2013.

COSTA, F.S.; BAYER, C.; ZANATTA, J.A.; MIELNICZUK, J. Estoques de carbono orgânico no solo e emissões de dióxido de carbono influencia das por sistemas de manejo no sul do Brasil. Revista Brasileira de Ciência do Solo, v.32, n.1, p.323-332, 2008.

COSTA, O.V.; CANTARUTTI, R.B.; FONTES, L.E.F.; COSTA, L.M.; NACIF, P.G.S.; FARIAS, J.C. Estoque de carbono do solo sob pastagem em área de Tabuleiro Costeiro no sul da Bahia. Revista Brasileira de Ciência do Solo, v.33, p.1137-1145, 2009.

DESJARDINS, T.; BARROS, E.; SARRAZIAN M.; GIARDINA, C.; MARIOTTI, A. Effects of forest conversion to pasture on soil carbon content and dynamics in Brazilian Amazon. Agriculture Ecosystems \&

Environment, v. 103, n.2, p.365-373, 2004.

EMPRESA BRASILEIRA DE PESQUISA AGROPECUÁRIA - EMBRAPA. Manual de métodos de análise de solo. 2.ed. Rio de Janeiro: 1997. 212p. (Embrapa-CNPS.

Documentos; 1).

FEARNSIDE, P.M. Mitigation of climatic change in the Amazon. In: LAURANCE, W.F.; PERES, C.A. (Ed.) Emerging threats to tropical forests. Chicago: University of Chicago Press, 2006. p.353-375.

FRAZÃO, L.A.; SANTANA, I.K.S.; CAMPOS, D.V.B.; FEIGL, B.J.; CERRI, C.C. Estoques de carbono e nitrogênio e fração leve da matéria orgânica em Neossolo Quartzarênico sob uso agrícola. Pesquisa Agropecuária Brasileira, v.45, p.1198-1204, 2010.

GRAÇA, M.A.S.; ZIMER, M. Leaf toughness. In: GRAÇA, M.A.S.; BÄRLOCHER, F.; GESSNER, M.O. (Ed.). Methods to study litter

Revista Árvore, Viçosa-MG, v.40, n.2, p.197-208, 2016

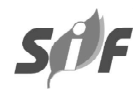


decomposition: a pratical guide. New York: Springer, 2005. p.109-113.

HICKMANN, C.; COSTA, L.M.; SCHAEFER, C.E.G.R.; FERNANDES, R.B.A.; ANDRADE, C.L.T. Atributos físico-hidricos e carbono orgânico de um argissolo após 23 anos de diferentes manejos. Revista Caatinga, v.25, n. 1, p.128-136, 2012.

HUGAR, G.M.; SORAGANVI, V.S. Impact of soil organic carbon on bulk density and plasticity index of arid soils of Raichur, India.

International Research Journal of Environment Sciences, v.3, n.2, p.48-58, 2014.

HUNTINGFORD, C.; HARRIS, P.O.; GEDNEY, N.; COX, P.M.; BETTS, R.A.; MARENGO, J.A.; GASH, J.H.C. Using a GCM analogue model to investigate the potential for Amazonian forest dieback. Theoretical and Applied Climatology, v. 78, n.1, p.177-185, 2004.

INSTITUTO BRASILEIRO DE GEOGRAFIA E ESTATÍSTICA - IBGE. Maior estoque de carbono da região da Amazônia Legal está no solo. [acesso em: 27 jul. 2012] Disponível em: http://www.ibge.gov.br/home/.

JONES, C.C.; MCCONNELL, K.; COLEMAN, P.; COX, P.; FALOON, P.; JENKINSON, D.; POWLSON, D. Global climate change and soil carbon stocks; predictions from two contrasting models for the turnover of carbon in soils.

Global Change Biology, v.11, n.1, p.114166, 2005.

SILVA JÚNIOR, M.L.S.; DESJARDINS, T.; SARRAZIN, M.; MELO, V.S.; MARTINS, P.F.S.; SANTOS, E.R.; CARVALHO, C.J.R. Carbon content in amazonian oxisols after forest conversion to pasture. Revista Brasileira de Ciência do Solo, v.33, n.6, p.1603-1611, 2009.

LANZANOVA, M.E.; ELTZ, F.L.F.; NICOLOSO, R.; AMADO, T.J.C.; REINERT, D.J.; ROCHA, M.R. Atributos físicos de um Argissolo em sistemas de culturas de longa duração sob semeadura direta. Revista Brasileira de Ciência do Solo, v.34, n.4, p.1333-1342, 2010.
LORENZ, K.; LAL, R. The depth distribution of soil organic carbon in relation to land use and management and the potential of carbon sequestration in subsoil horizons. Advanced Agronomy, v.88, n.1, p.35-66, 2005.

LUCA, E.F.; FELLER, C.; CERRI, C.C.; BARTHÈS, B.; CHAPLOT, V.; CAMPOS, D.C.; MANECHINI, C. Avaliação de atributos físicos e estoques de carbono e nitrogênio em solos com queima e sem queima de canavial. Revista Brasileira de Ciência do Solo, v.32, n.2, p.789-800, 2008 .

LUIZÃO, R.C.C.; LUIZÃO, F.J.; PAIVA, R.Q.; MONTEIRO, T.F.; SOUZA, L.S.; KRUIJT, B. Variation of carbon and nitrogen cycling processes along a topographic gradient in a central Amazonian forest. Global Change Biology, v.22, p.592-600, 2004.

MAIA, S.M.F.; OGLE, S.M.; CERRI, C.E.P.; CERRI, C.C. Effect of grassland management on soil carbon sequestration in Rondônia and Mato Grosso states, Brazil. Geoderma, v.149, n.1, p.84-91, 2009.

MARLAND, G.R.J.; ANDRÉS, T.A.; BODEN, C.; BRENKERT, A. Global, regional and national annual $\mathrm{CO}_{2}$ emissions estimates from fossil fuel burning, cement production and gas flaring. 1751-1998 (revised in august, 2003), Rep. ORNL/ CDIAC/ NDP-030, Oak Ridge Natl. Lab., Oak Ridge, Tenn., 2008. [Acesso em: 20 set. 2008]. Disponível em: http://cdiac.esd.ornl.gov/ndps/ ndp030.html.

MARQUES, J.D.O.; TEIXEIRA, W.G.; REIS, A.M.; CRUZ JUNIOR, O.F.; MARTINS, G.C. Avaliação da condutividade hidraulica do solo saturada utilizando dois métodos de laboratório numa topossequência com diferentes coberturas vegetais no Baixo Amazonas. Acta Amazônica, v.38, n.1, p.193-206, 2008.

MARQUES, J.D.O.; TEIXEIRA, W.G.; REIS, A.M.; CRUZ JUNIOR, O.F.; BATISTA, S.M.; AFONSO, M.A.C.B. Atributos químicos, físicohídricos e mineralogia da fração argila em solos do Baixo Amazonas: Serra de Parintins. Acta Amazônica, v.40, n.1, p.1-12, 2010. 
MARQUES, J.D.O.; LUIZÃO, F.J.; TEIXEIRA, W.G.; FERREIRA, S.J.F. Variações do carbono orgânico dissolvido e de atributos físicos do solo sob diferentes sistemas de uso da terra na Amazônia Central. Revista Brasileira de Ciência do Solo, v.36, n.2, p.611-622, 2012.

MUTUO, P.K.; CADISCH, G.; ALBRECHT, A.; PALM, C.A.; VERCHOT, L. Potential of agroforestry for carbon sequestration and mitigation of greenhouse gás emissions from soils in the tropics. Nutrient Cycling in Agroecosystems, v.71, n.1, p.43-54, 2005.

NAVARRETE, I.; TSUTSUKI, K. Land-use impact on soil carbon, nitrogen, neutral sugar composition and related chemical properties in a degraded Ultisol derived from volcanic materials in Leyte, Philippines. Soil Science and Plant Nutrition, v.54, p.321-331, 2008.

NEPSTAD, D.C.; CARVALHO, C.R.; DAVIDSON, E.A.; JIPP, P.H.; LEFEBVRE, G.H.; NEGREIROS, E.D.; SILVA, T.A.; STONE, S.E.; TRUMBORE, S.E.; VIEIRA, S. The role of deep roots in the hydrological cycles of Amazonian forests and pastures. Nature, v.372, p.666-669, 1994.

OLIVEIRA, J.T.; SANTOS, A.M.S.; MOREAU, A.M.; MENEZES, A.A.; COSTA, O.V. Características físicas e carbono orgânico de solos sob diferentes tipos de uso da terra. Revista Brasileira de Ciência do Solo, v.32, n.1, p.132-138, 2008.

POTTER, C.S.; DAVIDSON, E.A.; KLOOSTER, S.A.; NEPSTAD, D.C.; NEGREIROS, G.H.; BROOKS, V. Regional application of an ecosystem production model for studies of biogeochemistry in Brazilian Amazonia. Global Change Biology, v.4, p.315-333, 1998.

RAMOS, F.T.; MONARI,Y.C.; NUNES, M.C.M.; CAMPOS, D.T.S.; RAMOS, D.T. Indicadores de qualidade em um Latossolo Vermelho-Amarelo sob pastagem extensiva no pantanal matogrossense. Revista Caatinga, v.23, n.1, p.112-120, 2010.

SALIMON, C.I.; WADI, P.G.S.; MELO, A.W.F. Dinâmica do carbono na conversão de floresta para pastagens em argissolos da formação geológica solimões, no sudoeste da Amazônia. Revista de Biologia e Ciências da Terra, v.7, n.1, p.29-38, 2007.

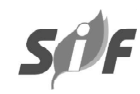

SARMIENTO, G.; PINILLOS, M.; GARAY, I. Biomass variability in tropical American lowland rain forests. Ecotropics, v.18, n.1, p.1-20, 2005.

SANTOS, R.D.; LEMOS, R.C.; SANTOS, H.G.; KER, J.C.; ANJOS, L.H. Manual de descrição e coleta de solos no campo. 5.ed. Viçosa, MG: Sociedade Brasileira de Ciência do Solo, 2005. 100p.

SEGNINI, A.; CARVALHO, J.L.N.; BOLONHEZI, D.; MILORI, D.M.B.P.; SILVA, W.T.L.; SIMÕES, M.L.; CANTARELLA, H.; MARIA, I.C.; MATIN-NETO, L. Carbon stock and humification índex of organic matter affected by sugarcane straw and soil management. Scientia Agrícola, v.70, p.321-326, 2013.

SILVA JÚNIOR, M.L.; DESJARDINS, T.; SARRAZIN, M.; MELO, V.S.; MARTINS, P.F.; SANTOS, E.R.; CARVALHO, C.J.R. Carbon content in Amazonian Oxisols after Forest conversion to pasture.

Revista Brasileira de Ciência do Solo, v.33,p.1603-1611, 2009.

SISTI, C.P.J.; SANTOS, H.P.; KOHHAN, R.; ALBES, B.J.R.; URQUIAGA, S.; BODEY, R.M.. Change in carbon and nitrogen stocks in soil under 13 years of conventional or zero tillage in southern Brazil. Soil and Tillage Research, v.76, n.1, p.39-58, 2004

SOIL SURVEY STAFF. Keys to soil taxonomy. Washington: Natural Resources Conservation Service; 1998.

SOMMER, R.; DENICH, M.; VLEK, P.L.G. Carbon storage and root penetration in deep soils under small-farmer land-use systems in the Eastern Amazon region, Brazil. Plant and Soil, v.219, p.231-241, 2000.

SPERA, S.T.; SANTOS, H.P.; TOMM, G.O.; FONTANELI, R.S. Avaliações de alguns atributos físicos de solo em sistemas de produção de grãos, envolvendo pastagens sob plantio direto. Revista Científica Rural, v.9, n.1, p.23-31, 2004.

STALLCUP, L.A.; ARDÓN, M.; PRINGLE, C.M. Does nitrogen become limiting under high-P conditions in detritus-based tropical streams? Freshwater Biology, v.51, p.1515-1526, 2006.

Revista Árvore, Viçosa-MG, v.40, n.2, p.197-208, 2016 
TRUMBORE, S.E.; DAVIDSON, E.A.; CAMARGO, P.B.; NEPSTAD, D.C.; MARTINELLI, L.A.

Belowground cycling of carbon in forests and pastures of Eastern Amazônia. Global

Biogeochemical Cycles, v.9, p.515-528, 1995.

VELDKAMP, E.; BECKER, A.;

SCHWENDENMANN, L.; CLARK, D.A.;

BISPING, H.S. Substantial labile carbon stocks and microbial activity in deeply weathered soils below a tropical wet forest. Global Change Biology, v.9, p.1171-1184, 2003.

ZINN, Y.L.; LAL, R.; BIGHAM, J.M.; RESCK, D.V.S. Edaphic controls on soil organic carbono retention in the Brazilian Cerrado: Texture and mineralogy. Soil Science Society of America Journal, v. 71, p.1204-1214, 2007. 